\title{
MONEY, MORALITY, AND POLITICS IN THE SLUMS OF BUENOS AIRES
}

\author{
Ariel Wilkis* \\ Consejo Nacional de Investigaciones Científicas y Técnicas / Universidad \\ Nacional de San Martín - Argentina
}

\begin{abstract}
Studies on the political life of the poor in Latin American have rarely focused on money, although there have been works focused on the survival strategies of the poor; political clientelism; and collective mobilizations. In this article, I analyze political life in the poor neighborhoods of Greater Buenos Aires through the lens of money that circulates within the Peronist networks. I conducted ethnography fieldwork between 2006 and 2010. Does money have a legitimate role in politics? Has the monetization of political activities dissolved values, commitments, and loyalties among the poor? Is this corruption, or is this an ethical exchange among people who lack cash but possess moral capital? Here, I analyze how money becomes necessary to strengthen commitments, loyalties, obligations, expectations, and plans for both leaders and activists. Reconstructing this process can provide a foundation for the revision of place of money in political life.
\end{abstract}

Keywords: money, politics, poor, slums.

Resumo: Estudos sobre a vida política dos pobres na América Latina raramente têm se focalizado no dinheiro, embora tenha havido trabalhos voltados para as estratégias de sobrevivência dos pobres, clientelismo político e mobilização coletiva. Neste artigo, analiso a vida política nos bairros pobres da Grande Buenos Aires através da lente de dinheiro que circula nas redes peronistas. Eu realizei meu trabalho de campo etnográfico entre 2006 e 2010. O dinheiro tem um papel legítimo na política? Tem a monetização das atividades políticas dissolvido valores, compromissos e lealdades entre os pobres? Isso é corrupção ou uma troca ética entre pessoas que não

* Contact: ariel.wilkis@gmail.com.

Horizontes Antropológicos, Porto Alegre, ano 22, n. 45, p. 49-76, jan./jun. 2016 http://dx.doi.org/10.1590/S0104-71832016000100003 
têm dinheiro, mas possuem capital moral? Aqui, analiso como o dinheiro torna-se necessário para reforçar compromissos, lealdades, obrigações, expectativas e planos para ambos, os líderes políticos e os ativistas locais. Reconstruir esse processo pode fornecer uma base para a revisão do lugar do dinheiro na vida política.

Palavras-chave: dinheiro, favelas, pobre, política.

In 2008 I met Mary during my fieldwork. She was ill. A few years ago she found out that she has a tumor. Sometimes the disease takes over and she needs to rest. Her sons and daughter take care of things at home and keep her company. Mary is a fifty-eight-year-old woman who lives in Villa Olimpia, a villa miseria (slum) in Greater Buenos Aires west of the country's capital city. Mary and her four children arrived from Paraguay twenty-five years ago. ${ }^{1}$

The neighbors know that when Mary does not come with them to see Luis Salcedo, the local political boss, it is because she is ill. She gets paid for her work as an activist, 'a political salary,' she likes to clarify. In Villa Olimpia, Mary isn't the only one who received money in exchange for her work to expand Salcedo's political career. A lot of local residents receive a political salary, since the higher up the local leader goes, the more people are needed to consolidate this growth. At the same time, more and more financial support is provided by the national government to ensure that Salcedo and his people continue to express their support for the administration's initiatives. For Mary and other residents of the neighborhood involved in politics in exchange for payment, this political money brings its own uncertainties: it is rarely clear how much they will get or when they will be paid. Nevertheless, Mary does what is expected of her for this "job", visiting her neighbors, resolving their problems on behalf of Salcedo and inviting them to rallies and demonstrations. Then she waits.

Waiting for the money affects her mood. When it takes longer than she expects, Mary gets angry at Salcedo and avoids him for a couple of days. If she feels depressed, she goes to talk to the local priest. Although the

1 Paraguayan migrants constitute the most numerous group of foreign residents in Argentina, with nearly 325,000 Paraguayans living in the country (Cerruti; Parrado, 2006). Traditionally, they have occupied low-level jobs, especially jobs requiring little or no qualifications in the service and construction sectors.

Horizontes Antropológicos, Porto Alegre, ano 22, n. 45, p. 49-76, jan./jun. 2016 
problems are monetary, they affect her emotionally. She feels supported by the priest, who always offers her some calming words. "Tell him to put his money where his mouth is," the priest says. The advice comes from someone who knows how to manage money in a context in which material needs, politics, and emotions all come into play. Cash donations to his church represent recognition of his work: local companies or rising politicians provide him with this donated money.

It would be hard to describe Mary and her family's everyday life without explaining her relationship to political money. How can her suffering, concerns, dreams and hopes be understood without it? By excluding money from this narrative, a portion of Mary's inner world would be relegated and silenced. At the social level, excluding money would also leave important gaps. It would also be hard to understand her relationships with her family, neighborhoods, and political boss if we do not understand her relationship to money.

In sociology, political anthropology and political science, there is a long list of works on clientelism (Eisenstadt; Roniger, 1984; Gellner, 1986; Schmidt et al., 1977; Scott, 1969). Latin America is no exception to this trend (Archer, 1990; Auyero, 2001; Kuschnir, 2000; Menéndez-Carrión, 1986; Vommaro, 2010). Fewer works focus specifically on money; one example is Vilella's work on Brazil (Vilella, 2004). In this article, I analyze political life in the poor neighborhoods of Greater Buenos Aires through the lens of money that circulates within the Peronist networks. ${ }^{2}$

I conducted ethnography fieldwork between 2006 and 2010. This research involved walking alongside party members as they took care of daily political duties in their neighborhoods; accompanying them to demonstrations, meetings, and rallies; speaking with them in their homes; and getting to know their families. I was thus able to understand money's central role in the political sociability of the lower classes. Here, I analyze how it becomes necessary to strengthen commitments, loyalties, obligations, expectations, and plans for both leaders and activists. Reconstructing this process can provide a foundation for the revision of place of money in political life.

2 Peronism is the political movement that has been historically associated with the Argentine poor since its founding by Juan Domingo Perón-three-time President, 1946-51, 1951-55 and 1973-1974-in the forties. 


\section{Moral sociology of political money}

The use of money in political exchanges has long been condemned. It is a preferred topic when reporting on the corrupt, biased practices that occur during electoral battles (Offerlé, 2011). In Street corner society (1943), W. F. White (1973) describes the circulation of money based on its reduced capacity to affect the bonds between political leaders and their followers. When viewed from the perspective of suspicion (Wilkis, 2013), that is, when money is exclusively associated with individualistic social orders with no relation to social cohesion, the positivity of political money remains hidden.

In The social meaning of money, Zelizer (1994) analyzes the expansion of money in the United States at the end of the nineteenth century and the beginning of the twentieth century. This process, far from homogenizing the meaning of money, showed the variable connections between its uses and its moral meanings. In this work and those that followed (Zelizer, 2005), the author worked to consolidate the idea that money is not hostile to morality and the moral dimension of money is not one-sided. These two ideas are behind what Zelizer refers to as "relational work," that is, the use of money to affirm, question or dissolve social ties.

This article continues these reflections on money. When separated from one-sided moral attributions of meaning, money emerges as a test of worth (Boltanski; Thévenot, 1991) for people and their social ties. These individuals are compelled to measure and assess themselves and others, creating hierarchies through money. While in circulation, money brings with it moral hierarchies and sketches a social order where people position themselves and others. The moral sociology of money that I propose analyzes how moral hierarchies take shape through the dynamics of money, revealing how these contribute to expressing and giving shape to conceptions of social order. Money is a great social classifier that allows the virtues and defects that establish human hierarchies to be judged. The use of money distributes recognition, transmitting virtues and putting people to the test. I am basing this perspective on the concept of moral capital.

Pierre Bourdieu's work to develop the concept of symbolic capital created an investigative framework for analyzing the different forms of recognition that confer power and legitimacy (Wilkis, 2014). The different subspecies of symbolic capital require different types of recognition. For 
example, agonistic capital (Mauger, 2006) recognizes skill in the use of physical violence. Erotic capital (Hakim, 2010) acknowledges adeptness at seduction. The concept of moral capital is another subspecies of symbolic capital.

People are constantly measuring, comparing, and evaluating their moral virtues because recognizing these virtues constitutes a very specific kind of power. To possess moral capital is to have these virtues acknowledged. For example, meeting one's moral obligations can be a source of such recognition (Mauss, 2000).

The concept of moral capital identifies this type of recognition and the way it ranks people in relation to the benefits of a social order. Therefore, there is an intimate connection between moral capital and the legitimacy of social hierarchies (Dumont, 1966). This involves observing the moral universe not as neutral but as agonistic-a field where differences can be determined.

People can be good for the money; they can be loyal, respectable, generous and hard-working; or disloyal, unreliable, greedy, and lazy. These are only some of the classifications gathered during my research; they are moral judgments that people reach or impose on others. They are terms that arise during a conflict, ones that reveal the dispute to define the moral boundaries that allow money to circulate or keep I t from circulating.

\section{A villa miseria transformed}

In poor neighborhoods, money that circulates as a result of political connections is nothing new. The way in which political networks inject economic resources into these neighborhoods has been examined in the context of the return to democracy in the 1980s (Ossona, 2014); the neoliberal reforms during the 1990s (Auyero, 2001); and in Argentina's poorest provinces (Vommaro, 2010). In Villa Olimpia, I consistently encountered this far-reaching practice of mixing money with political relations. In order to put this interpretation into perspective, it is important to consider two interconnected processes. Since 2003, Argentina began a series of reforms that gradually diminished the country's level of poverty, reduced unemployment, increased welfare and improved urban infrastructure (Kessler, 2014). These general trends were accompanied by specific transformations in the neighborhood of Villa Olimpia.

In 2006 when I visited Villa Olimpia for the first time, an urbanization was underway. Financed by different government entities and international 
organizations, the project aimed to modify the typical features of these relegated spaces, opening up streets to replace the corridors, ${ }^{3}$ constructing new residences and providing infrastructure (light, water, community centers). To achieve these goals, the state assigned a significant amount of monetary resources to the neighborhood to construct houses, pay the salaries of workers, and provide welfare assistance for other residents.

In the history of Villa Olimpia, October 1999 marked the start of a new period. A group of locals got together to occupy some neighboring land, around twenty hectares belonging to the company Gas del Estado. A series of different factors led to the occupation, including the accusation that neighborhood leaders had been embezzling funds; the frustration over promises not met by different administrations; and the sluggish growth of the population in the district. ${ }^{4}$ The empty lot allowed the locals to dream of their own decent home. For several months, a group of locals camped out there. They sketched out lots and organized a new co-op to replace the old co-op, which people no longer trusted. Everyone seemed to agree that Luis Salcedo was the new leader of this process.

In fact, Salcedo's main virtue was his political inexperience, which contrasted with the negative reputation of the old leaders of Villa Olimpia. The success-that of the urbanization project and the new leader-depended on closer ties with the elected officials and with Peronist party members, the main supporters of both the project and the leader. A political network sprung up around Salcedo, one partially based on his family ties. One of his nieces remembered this moment very clearly:

"To start urbanizing and do all of this, you've got to be involved in politics," said Salcedo's niece.

“That's right. If that's what it takes to get yourself a house,” I said.

"From there on, we're in up to here," she said, pointing to her forehead.

"A project changing the neighborhood after fifty years" was the phrase repeated by the members of Salcedo's network time and again. The phrase represented the transformation of the balance of power at the level of political rhetoric. This widespread perception was also present in a brief lesson that a

\footnotetext{
3 Slums are organized not by city blocks but by "corridors" too narrow for automobiles.

4 From 1992 to 2008, the population of Villa Olimpia expanded from 1,000 to 1,600 families.
} 
neighbor offered me as he pointed out Salcedo's house: "If you want to know how all this works, look that way. It all starts there.”

The process of urbanization and Salcedo's political growth created a political market increasingly centered on the circulation of money. The stories of Analia, Ricardo and Beto Ramirez help us understand this process and both its personal and collective effects. I will later return to the story of Mary that opened up this article in order to analyze how money works as political payment.

\section{Analia: money for everyone}

Like other women who come from Paraguay, Analia started off working as a maid at the beginning of the 1970s. Later she got a job in a textile factory. Some coworkers at the factory told her that she could buy a lot in a slum in the western district of Greater Buenos Aires and she jumped at the opportunity. With the support of her fellow Paraguayans, she built the first room of her house. However, her process of integrating into life in Villa Olimpia was interrupted when her father fell ill and Analia was forced to return to Asunción. She came back fifteen years later. She had married in the interim and she again chose to settle in Buenos Aires with her four daughters after splitting up with her husband.

During the feverish excitement of the occupation in 1999, Analia was an active participant. She didn't think twice about occupying a piece of land that she divided up with her daughters. Together they set up a tent where they slept during the long months of the occupation. As a precautionary measure, Analia almost never left them alone, especially at night. They were still quite young and she was afraid of leaving them on their own on an empty lot with no lighting.

Analia cooked for the entire group, which spent day after day on the land, never leaving. The dream of owning a house of her own seemed well worth it. Because of her participation in the occupation, she became part of Luis Salcedo's incipient political network. Like everyone in Villa Olimpia, she had known the future neighborhood leader since he was a boy. Analia remembered him playing soccer on the streets and working at the local bakery. When the group had been assured they would not be evicted, Analia became a delegate. She was in charge of collecting the payments that had to be made to make the land purchases legal. The new house would be constructed with welfare funds allocated by the government. The year 2004 was an unforgettable one: the family moved into its new house. 
As time passed, the slum began to experience other changes in addition to the transformations to the urban grid. The urbanization project had created new jobs associated with Salcedo's network that differentiated the residents. A new joke circulated in the neighborhood: "Here in Villa Olimpia, there's a secretary under every stone.” In fact, a dispute with one of Salcedo's secretaries made Analia decide to withdraw her support for Salcedo. One day Analia went into the co-op office with the money she had collected. When the secretary saw that she had not had a good day, she tossed the wad of bills onto the desk. Then, giving Analia a dirty look, she gestured for her to leave.

Analia was offended by the treatment she received. It wasn't as much a personal affront as it was a snub to the efforts of her neighbors, who had saved that money to make the installments on their future homes. She told Salcedo, "I'm not pleased with what happened. I'm done here." The fact that Analia had decided to distance herself from the movement was indicative of other changes that were occurring at Villa Olimpia. She was in an ambiguous and thus painful position. As a member of the founding group of Salcedo's social network, she had bet on the leader's growth but she had been excluded from these new types of political recognition.

"It hurts, you know? I mean when push came to shove, when they (the co-op members) were going to get salaries, they didn’t call me. I don't understand why they didn't call me,” said Analia.

The salary was directly indicative of the transformation of the political exchanges in Villa Olimpia. This money, clearly political money, which she did not earn in spite of all her work for the network, left her feeling undervalued, as if Salcedo had not acknowledged her work. Moving away from the network meant protecting herself from defeat in the struggle to accumulate moral capital.

It is useful to think of Analia's departure from the network not in absolute terms but as a waiting period. Analia's day-to-day contacts still included Salcedo's people, family members and other neighbors who were still part of the network. Things began to happen as time passed. As Analia expected, political salaries became more and more common in the neighborhood. She took note and brought it up with Salcedo every time she ran into him. "When you've got something that could work for me, let me know. I'm ready to do whatever you need."

Salcedo did in fact remember, but not the way Analia had expected. He offered to take out a loan so that she could buy a sewing machine. However, 
it was clear that this lent money was not the same as political money. Both were types of money that reflected two positions of the moral capital that joined Salcedo and Analia. From the Paraguayan woman's relegated position in the network, she could access a loan, but in order to earn a salary, she had to again prove her political virtues and have them be acknowledged by the network. Once again, she would have to accumulate moral capital under the terms that governed the political exchanges between Salcedo and his followers.

At last the day arrived. On the dining room table of Analia's house, there was a notebook with a list of names of the kids who played soccer in the neighborhood. Analia had already spoken with the local mothers and she wanted to tell Salcedo about her project to put together a kid's soccer team.

She had been planning this for some time, when she had been invited to join the Villa Olimpia Sports Commission. At that point, Salcedo had spoken with the future commission members.

"There won't be a salary at the beginning but there will be eventually," he said. And then, as if to emphasize the last point, he added, "You're going to have to work hard.”

Analia already had a work project laid out and she was hoping to speak with Salcedo, to show him that she had in fact been hard at work since leaving the network. In a meeting of groups from different slums in La Matanza district, she asked to speak in order to present her project.

"I used to be part of the co-op but I got derailed, derailed like an old train. I went off the tracks, I lost my way," she declared as an introduction. "But today I'm back with a whole new purpose. I want to work with kids.”

The political money appeared in Analia's expectations like a clear indicator that she was being reincorporated to Salcedo's network. Receiving this money would make her feel part of the group and make her relegation a thing of the past. This political money indicated that her derailed train was now back on track and rolling.

\section{Ricardo: the contradictions face the politica/money}

I met Ricardo, a fifty-year-old man, in my first visit to Villa Olimpia. He had retired from Argentina's border patrol and at one point, he had owned his own auto repair shop. He had now been living in one of the new houses 
for the past three years. In addition to his second wife Paula, his youngest son, the nineteen-year-old Pepe, lived with him as well. The elder son, who was twenty-one, lived with his girlfriend and daughter in his mother-in-law's house, which was also in the neighborhood.

I left before the end of lunch at Ricardo's home because I had been invited to accompany some of the neighborhood residents going to see President Cristina Fernández de Kirchner speak. A few miles from the neighborhood, a sewage network was being inaugurated and the ceremony was overshadowed by the executive branch's conflict with farmers in the countryside. For the political leaders of Villa Olimpia, it was a critical moment to stand by the president.

As we ate, the noise of the drums mixed with our conversation. The drums were being played to encourage the residents to come out for the rally. As the departure time neared, the drums grew louder and louder. With this noise in the background, Ricardo reflected on his involvement with politics.

"I don't get involved unless they're protesting for things associated with the neighborhood. Important stuff."

He provided details during lunch to support his argument. Yet when I stood up, apologizing for having to leave early to catch the bus to the rally, Ricardo grabbed his jacket and said, "I'll come with you." As we walked over to where the political group was congregating, I couldn't help but wonder what Ricardo was doing there. Had he not been honest about his position on these rallies? At a glance, this rally wouldn't classify as an “important” one, according to his description.

Perhaps my own interest had suggested to him that this rally might indeed be important, placing it in the category of rallies he did in fact attend. However, months later, Ricardo would clarify his motives. He had also stood with Salcedo's group at rallies organized by the government. When he understood that I considered this important, his story changed: "You know what? I went for the same reasons you did.”

It then occurred to me that Ricardo's ambiguous stance on the rallies and the protests revealed the nature of political ties within the neighborhood.

At all times, Ricardo attempted to distance himself from politicians and from the way they employed resources such as money. His discursive performance-not attending rallies, criticizing Salcedo's group for not really working for the neighborhoods, pointing out unfinished or badly constructed houses, criticizing under-the-table agreements for new housing projects-was 
consistent whenever he was with me. However, although Ricardo distanced himself from the neighborhood politics in his discourse, in his actions, he made an appearance and participated in almost all political demonstrations he was asked to attend.

Although discursively Ricardo established a distance from the set of opinions and feelings associated with political money, his participation indicated that he in fact complied with the principles associated with this piece of money. The moral capital associated with political money meant being acknowledged for participating in rallies and other activities to support the leader. Accepting the invitations and attending the rallies and marches to show his loyalty towards Salcedo were sources of moral capital in politics.

One interesting point of this ambiguity was the way in which Ricardo and one of his sons tried to position themselves with respect to money that circulated from the political network. His youngest son, Pepe, was a musician in the neighborhood murga, and he joined some of the discussions I had with Ricardo in August 2008. He told me that he had been promised AR $\$ 150$ for each member of the band.

"But they didn't follow through. And on top of it, they gave other people work."

He believed he was more entitled to the money. After all, he had gone to all the marches. He had been there. "Pepe is really irked at Salcedo," Ricardo clarified. "He says he's going to talk to him tonight. Salcedo promised him a job in construction working on neighborhood housing-a job for him and all the boys who play in the murga.”

For the first time, Ricardo was revealing a curiosity similar to my own as a justification for going to the rallies and demonstrations. To let Pepe know that he believed his son had been wrong to trust Salcedo, Ricardo listed his own many requests for work. "I never got a thing from him," he said, adding that it was because of his involvement in the parish.

Pepe pointed out Salcedo's house.

“That's where it all starts. He’s playing the boys in the murga for fools. All of us have families and we're willing to work for the money, not just take kickbacks. We play in the neighborhood all the time. It takes a lot of practicing."

"If you see it's not working out there, you have to find a way out and look for something else,” Ricardo advises. 
"But if I quit, this guy'll forget all about me."

Ricardo turns to me. "I told him this year to start trade school, that way he learns something and maybe gets a job."

For Pepe, it was hard to get used to the idea of getting a job that would provide him with a salary outside the Villa Olimpia political network. With his words, Ricardo was trying to convince him of a more legitimate way of earning a living: going back to school and learning a trade. He wanted to teach Pepe to seek out money other ways, not through political money.

Ricardo was unemployed. The times in which he had owned his own auto repair shop were long gone, though the memories lingered. He would draw on these memories when speaking to Pepe about his future and giving him advice about what to do. However, the fact of the matter was that Ricardo was inadvertently legitimizing political money in his discussions with his son. All his talk about Pepe returning to school hit up against Pepe's anxious need to earn a living and did not respond to Pepe's feeling of having been let down by Salcedo after showing up for so many events.

The contradiction was even more palpable when Ricardo explained how he was never considered because he belonged to the parish. Pepe rolled his eyes; he had clearly heard this many times before. Those not involved with the religious group, which competed with the political network to some degree, were much more likely to receive the benefits the political network offered. This was the case of Pepe, who considered that Salcedo's house was "where it all starts." His belief was inadvertently fostered by his father, who in his own way tried unsuccessfully to get to the leader.

Pepe continued to attend the rallies with the murga. Ricardo acknowledged his son's expectations. "Now let's see what's going to happen."

Finally, Pepe got a job through Salcedo.

\section{Beto Ramirez: money and political competition}

I heard the name Beto Ramirez before actually meeting him. Everyone had something to say about Beto, a Peronist activist for many years. The Ramirez family was also a political group and Beto served as the family spokesperson in addition to his regular political activity. His name was painted on the walls both in the neighborhood and in neighboring ones. Beto was in the same party as Salcedo and he was in the same political faction of Peronism 
in La Matanza. Thus, his career had been blocked by the transformation of the political field that had started with the urbanization process.

Once I had won his trust, he also invited me to walk through the neighborhood with him.

"I know that they showed you what they [Salcedo's group] wanted you to see. I'm going to show you the truth,” he said.

Since I had already visited the neighborhood with his rivals, Ramirez wanted to change the idea he believed I had about Villa Olimpia. It was not only because he had seen me several times with Salcedo's cronies. It was also because of who I was-an outsider, a university researcher-which automatically put me into the category of guest on the official visit. I had to be shown an image other than the one presented by Salcedo's group. I had to "walk the neighborhood" with him.

During the walk, we met families who were angry (they still hadn't moved) and saw new houses suffering from infrastructure issues and others that had been illegally transferred. On our walk, the neighborhood was presented in a new configuration in which Salcedo and his group were judged negatively.

This journey through the neighborhood and the criticism of Salcedo made it perfectly clear that politicians aspiring for leading positions in the community vied for moral capital. Ramirez made me hear all the voices speaking out against Salcedo, most of which attacked the leader's moral capital. Salcedo claimed to improve the lives of the Villa Olimpia residents, but these voices spoke of promises unmet and of the special privileges of Salcedo and his cronies.

The people we met along the way offered variations on the Ramirez perspective. Salcedo was criticized for affecting the political career of Ramirez and his family. It seemed as if revealing the gaps in the official story of the urbanization process was a way to rectify this situation.

"Would you like to come see the graffiti?" asked Ramirez.

He wanted me to see that he was also working hard during the days leading up to the Peronist primaries.

"I am far from dead politically, which is what Salcedo’s people would have you believe."

His zeal whenever Salcedo's name was mentioned made it clear that he was on the defensive. He got anxious thinking about ways to change the unequal balance of power. 
"What do you think?"

He wanted my opinion on Salcedo's possibilities.

The wall graffiti announcing the candidacy of the neighborhood leader was signed by the Ramirez family. By showing me that he "wasn't dead", he was also reaffirming his subordination. For the time being, his political activity depended on accepting Salcedo's leadership. However, Ramirez was fearful of being totally eclipsed by the rising political figure. That is why he wasn't sure whether to accept Salcedo's invitation to walk through the neighborhood alongside the leader. If the locals saw them together, they would probably conclude that local politics now revolved exclusively around the figure of Salcedo.

Although Ramirez would try to avoid it for some time, he knew that he eventually would be forced to fall in line with Salcedo, which would mean giving up on his own political aspirations in the Peronist party of La Matanza and more broadly, in the province of Buenos Aires. His only hope was for the following year: the elections in the co-op would allow him to represent those who were displeased with Salcedo. He felt sure that his political luck would change.

While he planned for a better future and thought up ways to lead the neighborhood through the transition, Ramirez paused before a few young men who were painting Salcedo's name on one of the neighborhood walls. He pointed to one of them.

“That's exactly what I need: a guy who's earning a salary and who can be there when I need him. I'm going to talk to Salcedo to see about that, to make sure the boys who are with me get something like that, steady work.”

Ramirez compared himself with Salcedo constantly, as the leader mirrored his position in local politics. His own career was thwarted by Salcedo's growth as neighborhood leader. Political salaries were also a frequent point of comparison. Ramirez could not aspire to compete with Salcedo unless he could access political money to acknowledge the work of his own followers. The lack of such money brought his moral capital as a leader into question. Through such money, he could express his support and recognition of followers, show himself to be a politician with aspirations. As we saw in the story of Analia, followers expected to receive a political salary and their trust in a leader depended on it. Ramirez knew this was his Achilles heel in politics and that he could not compete with Salcedo without this tool that would allow him 
to be recognized as a true leader. Political salaries for his supporters would show them that Ramirez cared about them and that they could trust him-two signs of an up-and-coming politician.

\section{The unity of money}

The rumors that form deep within a group are not unconstrained; they are governed by the same rules and relations that bind the people within the group. Norbert Elias and John Scotson (1997) contributed to this perspective of rumors: they viewed them as indicators of the sociability of a group both because of the unity they inspire as well as the competition and conflict they spark. In Villa Olimpia, the rumors about political money were indicative of the new source of social unity and of moral conflicts that were produced by the spreading of this monetary puzzle piece.

"So-and-so is earning a salary. So why does he work so little? He's not earning much, but he's going to have to work harder," said one woman in the Father Suarez network to another member.

"You know that so-and-so earns regular wages for what she does?" asked one man in reference to a woman in Salcedo's group.

"I was surprised to hear that so-and-so has quit her job. I bet her and her husband are both earning a salary at the church,” said another man.

"Here at the church, we don't get paid, but Salcedo did offer me a subsidy. I didn't get it through him though-I got it through another guy I know who's with another party faction. I hope Salcedo doesn't find out," confessed a collaborator.

These kinds of rumors accumulated as my visits to Villa Olimpia continued. Each time, it became increasingly clear that the social intensity of political money sheds light on the way agents evaluate their mutual obligations. Money can be a source of defects and virtues precisely because it becomes a moral account unit.

In his book The philosophy of money, Georg Simmel (1996) explored the question of how money imbues social life with a generalized relationism. As its use increases, claimed the German sociologist, there are more opportunities for connections between people, things, situations and social ties. The generalization of political money involves a process of this kind. The salary or political payment had become a unit of the personal and collective life in 
Villa Olimpia. A common sociability was sustained through the opinions and the sensibilities connected to this type of money.

The spread of money in political exchanges did not affect one's moral obligations. On the contrary, it transformed the way in which these obligations are evaluated, justified, represented, and fulfilled. The uses of political money became a source of moral capital. The rumors and stories of Analia, Ricardo and Beto Ramirez reveal a new framework for judging obligations in which monetary calculations are mixed with moral judgments. Money provides an objective, numerical assessment of political commitment; it makes it feasible for economic value to enhance the moral value of people's actions and for it to be recognized as a political virtue or defect.

The hypothesis of the positivity of this monetary piece can be confirmed by considering how collective and individual conversions are encouraged through the spread of political money: this source of unity and moral conflict pervaded social life in Villa Olimpia. In order to revise the concepts of money in the political life of the poor, we must internally explore the regime of feelings and perspectives about political money and discover exactly how it works-not only as a compensation for tasks performed, but also as a moral account unit.

\section{A world of money and obligations}

Mary and her family were living in a rickety house in the poorest area of Villa Olimpia: a settlement consisting of six city blocks that had been left out of the urbanization plan. For this reason, the residents there felt like they were on the lowest rung of the social ladder of the neighborhood. They watched with anger and sometimes with envy as their neighbors-who were often relatives-gained access to a more comfortable living situation.

Mary knew she had the support of the other residents of the settlement. With the help of Father Suarez, she had set up a soup kitchen. Since she had previously worked as a cook, she knew how to successfully feed a hundred children. As time passed, Mary's house became the place where people came to get information, make a complaint or solve a problem. Her family had begun playing a major role in the neighborhood, a role that would become even more important once she and her family had definitely joined Salcedo's political network. This had occurred a good time before the transformations of the political sphere in Villa Olimpia. 
Before running for office, Salcedo had lacked the political capital he would need to control the neighborhood. The porosity of the settlement and its marginal nature favored rivalries among those trying to accumulate political power. Those from other groups (social movements, other factions of the Peronist Party) competed for the support of locals such as Mary by making a wide variety of promises (improvements to infrastructure, employment opportunities, access to municipal officials).

Mary intervened on behalf of Salcedo one summer afternoon when the political disputes were as heated as the temperature. It was still some time before Salcedo would begin receiving the daily support common of a consolidated leader; at that time, supporting Salcedo still represented a wager on an uncertain future. These gestures were highly valued because they occurred in a climate in which many looked unfavorably upon Salcedo's political aspirations.

That hot day, the leader of a social movement and his followers tried to take political control of the settlement. Salcedo was the first to intervene and declare himself against the move; he was followed by a few members of his still incipient network. The tension increased as the day wore on. When the argument became so heated that it looked like physical violence might erupt, Mary interceded on Salcedo's behalf. She convinced the local residents to say that they would side with Salcedo if things turned ugly.

Mary's gesture of support worked as a sort of primitive accumulation of moral capital. Salcedo found himself before someone who was wagering on his leadership and this was irrefutable proof of her virtues. It was evidence that Mary was a person worthy of trust, granting her the right to enter Salcedo's political network. This right was reserved for Mary's relatives and for the original members of the group that occupied the land in 1999.

After this incident, Mary abandoned the soup kitchen that she had organized for Father Suarez's parish. From then on, she would gear all her efforts to "accompanying" or "working" for Salcedo, as she liked to put it.

Several years after that episode, I went with Mary to town hall one day. She had been waiting for months on the documentation she needed in order for her Paraguayan children to become Argentine citizens. That morning, she had received a call to tell her that the paperwork was ready. During our bus ride, Salcedo called her cell phone constantly to tell her that he was afraid a conflict would break out among residents in the settlement. He was calling her to make sure she would take care of it. 
A young woman with several young children had occupied one of the lots without permission. She quickly managed to build a precarious tin house there. The owner of the lot, who also lived on the settlement, had given her a deadline for abandoning the lot. It was a delicate situation. Mary intervened.

"I'm speaking on behalf of Salcedo, who is well aware of the situation. We have to settle things on our own."

She spoke separately with the owner of the lot and with the young woman and later she organized a meeting to reach an agreement. The woman would be able to stay a few more months on the condition that she agreed to leave once those months had passed. Salcedo, for his part, would do everything possible to find a new lot for her.

Mary's main concern was to avoid conflict among the residents of the settlement. She knew that she could speak "on behalf of Salcedo" as long as she remained capable of maintaining political control of the settlement. And from that first moment when she mobilized the residents to support Salcedo against competing political groups, her best political investments involved fulfilling this obligation, that is, keeping control of the settlement. Her position in the network depended on it.

\section{A step back}

"During the presidential elections in 2003, I worked with Salcedo nonstop," said Mary. But suddenly she added, "In the 2007 [presidential] elections, I took a step back."

This was the first time Mary made reference to the time in which she had stopped working for Salcedo. It was a memory filled with anger and bitterness.

Mary was very disappointed when Salcedo picked not her but her niece to be in charge of the settlement. Her subjective experience corresponded to an objective reality, that is, that in his decision, Salcedo had overlooked the virtues of her “political work”. Taking “a step back” meant sending Salcedo a clear sign that she was upset about his decision to put her on the network's backburner.

A year later, Salcedo reversed his decision; Mary's niece had failed as the head of the settlement's organization. Mary had been waiting for this to occur in order to return to her previous political responsibility.

Mary spoke negatively about Salcedo a second time after an intensive series of rallies and demonstrations that the government had organized. It was 
just before Children's Day. "I'm not going to take part in the celebrations," said Mary. "I don't like the way (Salcedo) has organized things." Her words took me aback. I was surprised she wouldn't participate, after "accompanying"-Mary's favorite word-all the groups from Villa Olimpia that had left the neighborhood for President Cristina Kirchner's demonstrations and rallies. Oftentimes she would spend long days outside during cold weather and rain, not returning until nightfall.

Her words also left me with a question: would Mary be able in fact not to participate in an activity organized by Salcedo's group?

I later realized that my surprise was owed to an erred conclusion. I had not realized that Mary's words reflected only the current state of her ties with Salcedo. I had interpreted them without considering the open, fluctuating cycle of mutual obligations. Working for the leader implied that there was some balance to this cycle. Stepping aside meant expressing that she was not pleased by the fact that he was not fulfilling his mutual obligations to her.

Organizing the settlement and guaranteeing Salcedo's support were the guidelines for her actions and for her political commitment. This was the basis for Salcedo's recognition of Mary and these obligations represented the source of her moral capital. For that reason, it is important to understand what had happened in the months leading up to Mary's decision to step aside, that is, the political work during the cycle of rallies and what happened afterwards.

In this regard, one scene comes to mind. Mary was sitting in front of her house with her father and a friend. She had a list in her hand and from time to time she looked down the street to see if anyone was coming by.

"Are you coming to the event?" she called out to a young man who passed by the house.

The man responded that he wasn't because he'd found a job. However, he told her that his neighbor's kids would be there. Mary was fixated on her list. She was concerned about how the names are spelled and she asked me to write them down for her.

Two hours later, in a bus heading towards the city of Buenos Aires, we reached the highway tollbooth. A long line of school buses were waiting at the booths. They hailed from different places in the province of Buenos Aires and all were clearly heading downtown for the event. The bus was stopped for several minutes. I got out to see what the trouble is. One of the Peronist 
organizers had asked Mary to switch buses. She refused, as she has been assigned to bus number fifteen.

During the series of rallies, Villa Olimpia was like an orchestra without a director, to use the image of French sociologist Pierre Bourdieu (1990). It would be mistaken to position Salcedo as the director of these collective processes because he was part of the political exchanges just like the rest of the neighborhood's inhabitants. His career depended on the alliance with members of the government. As a result, he was obliged to mobilize the neighborhood residents as a sign of his strength. This, however, was something that did not depend entirely on him.

The rallies depended on the supply and demand for political support. Local language translated this meeting into two categories: inviting others along and being seen. In the days leading up to each event, the members of the political group and their leader would invite the Villa Olimpia residents to come with them, visiting them at home or taking advantage of brief conversations as they walked through the neighborhood. The response was not immediate, but instead depended on constructing Salcedo's demand for support.

Mary's political work consisted in reinforcing this imperative among the settlement residents. By getting them to participate in the rallies, they were invited to express their support for the political leader. "Once they know you (the network members), they ask, 'Why didn't so-and-so come?” explained Mary as she walked through the neighborhood inviting people to a new rally.

In one of these journeys, we met a resident who had stopped going to the marches after falling ill. Her health had worsened and she would probably not be able to travel on the bus for supporters again. Mary had prudently spoken to Salcedo about this woman's situation. When Mary spotted her, she told her not to worry, that she would receive all the drugs she needed to beat the illness. Before the conversation ended, Mary gave her some words of advice: "Tell your son to come to the march. That way, he can talk to Salcedo's wife. She can probably get you a sewing machine so you can get some work.”

Through interventions like these, Mary reiterated her belief in the virtue of being seen, a rule of thumb that applied to most political exchanges. Without that belief, one's offer to express support for Salcedo would not generate the corresponding demand.

The conviction that she helped give others was born from her own selfconviction. Her position on the market of political exchanges sustained the

Horizontes Antropológicos, Porto Alegre, ano 22, n. 45, p. 49-76, jan./jun. 2016 
obligations of organizing the support for Salcedo. Her moral capital, which was proportional to her awareness of the need to follow the rule, could be seen in how carefully Mary prepared the list, the transportation and the rest of the activities aimed at constructing support around Salcedo (letting people know in advance, getting the food and beverages ready for the trip, etc.) And it could also be seen in the number of people who attended because of her. This number was the objective indicator of both the obligations she fulfilled in the network as well as those which she assumed with the settlement's residents.

\section{Failing to fulfill obligations}

Mary used the expression "working for Salcedo" over and over again. It summarized the shifting balance of mutual obligations between Mary and Salcedo, along with her own obligations to the settlement's residents. Her position in the political realm depended on the configuration of these obligations.

When Mary decided to step aside, her political work was no longer associated with the name Salcedo. She could either associate her name with another network-word of her dissatisfaction got out and Beto Ramirez expressed interest in speaking with her-or simply put things on hold. By not participating in the Children's Day festivities, she was choosing to do the latter, that is, to exclude herself from an activity that attracted the whole neighborhood. "If I stop going, everyone starts talking,” she said, clearly bothered.

An innocent conversation about a stolen gas cylinder revealed that Salcedo's obligations had been thrown off balance with regards to Mary’s after the series of rallies. The intensive "political work" of those months had depended on mutual promises. Yet apparently her fulfillment wasn't worth enough to even entitle her to an object necessary for cooking meals. "Salcedo constantly says yes but then does nothing," she complained.

Someone had stolen a gas cylinder from Mary. ${ }^{5}$ When Salcedo found out, he told her not to worry, he would replace it. She waited for Salcedo-or Kuko, his right-hand man-to buy one for her or say something about getting her a new one, but there was no response. "I'm not buying another one,"

5 Most slums are not connected to the domestic gas network and thus must use gas cylinders for heating and cooking. After paying for the initial cylinder, users only pay a refilling charge. 
explained Mary. "Not because I don't have the money but because they said they'd get me one."

It was one disappointment after another. A year earlier, the house that served as the soup kitchen for snacks she served the children in the settlement had burned down. She was still waiting for Salcedo to give his approval for the reconstruction to begin. "I've got the Paraguayans here ready to start building! Meanwhile, the kids have to go to the church for their snack."

During our conversation, she got a call from one of Salcedo's nieces to ask her about how much milk and chocolate powder was needed to feed 1,000 boys and girls. "I'll get back to you," she said. It was a stark contrast from the old Mary, who used to drop everything to respond to people from Salcedo's network. Our conversation continued.

"I told Tamara [a woman who rented a room in Mary's house and who helped her to cook the food she sold on the Villa Olimpia soccer field] she had to go to the demonstrations so Salcedo would keep her in mind... But I didn't get anything for her! Do you think I should go talk to Beto Ramirez? If I work for Salcedo..."

She didn't give me time to answer. Instead she continued. "My daughter's house should already be finished. They had promised it for March. It's a joke! All of the neighboring houses are done, but not hers. I take money out of my pocket for the marches! I have to bring something to eat and drink for the murga. ${ }^{6}$ They send me the kids who are hungry, and I have to feed them. Salcedo knows that, which is why he gives me a hundred pesos for each demonstration."

The flow of goods, which had become more erratic over time, was comprised of qualitatively differentiated objects. They would acquire value based on the political exchanges that allowed them to be sustained; their absence made them questionable. This discontinuity in circulation destabilized Mary's position. It made her political work in the settlement difficult (not having an actual space for the children's snack) and also undermined her authority, because when the resources weren't available it was her name that was mentioned, not Salcedo's. The promises she had made were thus questioned, as were the obligations assumed.

6 Murga is a popular street performance. Drummers play and blow whistles while other performers dance. All wear colorful costumes and people of all ages participate.

Horizontes Antropológicos, Porto Alegre, ano 22, n. 45, p. 49-76, jan./jun. 2016 
I spoke with Tamara at one of the demonstrations that Mary had requested she attend with her children. She had never been to a rally before. She had to be seen-so that Salcedo would keep her in mind-because her husband had been arrested on drug trafficking charges. He would only get a conditional release from jail if he could certify he had a job. This was her request for Salcedo. Mary had assumed the obligation of getting her the certificate.

Mary was hurt by how weakened her authority was. She found out that Salcedo wasn't even going to be sending her provisions for Tamara and her children. How could she get Tamara the certificate she needed to get her husband out of jail? How could she guarantee it?

Mary's acknowledgment of her loss of authority also affected her family ties. How could she keep her position in the network and in the settlement if her own daughter had to wait to get her house built? How could Mary keep them on the same side-her sons, daughters, sons-in-law and daughters-inlaw-if she herself was having trouble getting goods that would be distributed among them? She needed her relatives to ensure the minimum number of people at rallies but she also needed them as support: they represented both a social and a moral force.

\section{A political salary}

In the end, Mary did not attend the Children's Day celebration, though not for the original reason she planned on missing it: a serious illness with which she had been diagnosed years before flared up on the day of the event. When I saw her again, I found her very concerned about her health but more conciliatory with regards to the political leader. "Everything's fine with Salcedo... I thought I was angry but he knows that when my illness flairs up, I disappear. He also knows that if something urgent comes up, I'm always there, no matter what."

Since her health had made it difficult to keep her place selling food on the soccer field, her household economy had suffered. While she had previously remained elusive when asked about the money she received from her work in the political network, her current situation allowed her to speak a bit more freely: "Salcedo knows my situation. He tosses a little something my way."

This "little something" consisted of a monthly salary of two hundred pesos and a supplement that varied depending on the situation. "When I need 
a little more, he gives it to me," she said. In this case, the supplement was an indication of Salcedo's concern for Mary's health. Mary explained that this money was "like" the monthly government allowance, "but not exactly." Unlike the conditional cash transference, the money she received was a personalized payment. With this type of conditional cash transfer, the amount varied depending on her current connection to Salcedo.

The reasons that had made Mary consider stepping aside faded away. In addition to the political salary, other transfers came from Salcedo's network. Her grandson received a scholarship for school; reconstruction began on the house for the soup kitchen; her daughter finally moved into her new house; and her youngest son had found a job with a construction co-op run by Salcedo's group.

The money circulated and thus Mary's fulfillment of her obligationsalong with her own political investments-was acknowledged. Salcedo asked her to speak of her work in the settlement during the affiliation campaign at meetings with the residents of other villas miserias in La Matanza.

Salcedo had once again shown that he could trust Mary, that he knew she would be there when he needed her. Mary recovered her hopes and her expectations for the future: finishing construction on her house and getting her children a "steady job," as she referred to the posts at town hall. The moral capital that connected her to Salcedo and to the political network guided these hopes. Mary confessed, however, that she never let her hopes extend more than a year into the future-that was the time she was willing to wait for them to come

Political money inspires expectation with regards to the future. This is the place where Mary's hopes for her children are configured. In the preface to the compilation Money and morality of exchange, Maurice Bloch and Jonathan Parry (1989) suggest that different cultures give different meanings to money depending on whether it is associated with short or long-term transactions. Short-term transactions are associated with competition and individualism; long-term transactions consolidate social ties. When a solvent vision of money prevails, its symbols are dissociated from long-term transactions. In contrast, for Mary political money represents a long-term wager to guarantee the continuity not only of Mary's family group but also of the political network and the position of its leader. Political money thus symbolizes the fulfillment of mutual obligations; it functions as a currency in the moral account of political ties and thus of social cohesion.

Horizontes Antropológicos, Porto Alegre, ano 22, n. 45, p. 49-76, jan./jun. 2016 


\section{Conclusion}

As we saw in this second part of the article, not only money circulates between Salcedo and his followers. Other things sustain their bond. Given the evidence, a few questions arise: what distinguishes political money from other means of exchange? What sets money apart from other monetary payments?

In this article, we have seen how political payment became the moral accounting unit to gauge the relationship between Salcedo, the members of his political network and the rest of the neighborhood inhabitants. The stories of Analia, Ricardo and Beto Ramirez-along with the rumors of political payments to loyal followers-show how money ranks higher than other exchange methods. Money does not have a unilateral value nor does it occupy a single position in social life. Here we have seen how a community transformed money to suit local political obligations and positioned it at the center of collective life.

To respond to the second question, we should remember that Viviana Zelizer (1996) identifies three monetary payments that people use to distinguish their social relations: gift, entitlement, and compensation. Which of these categories covers the meanings of the category of political money? I believe that each of these payments contributes to the meaning that the agents give this type of money. We can see this interpretation in the bond between Mary and Salcedo. Political money, on the one hand, took on the meaning of a gift. Mary emphasized how Salcedo showed his concern through money. When she was sick, the leader of the political network "threw a little something [her] way.” However, other meanings also emerged such as entitlement (the words used to voice her complaint and the fair distribution that gave meaning to the money) and compensation (Mary kept accounts of all the activities she did as part of her "political work"). These three aspects thus came into play, though not without conflict, in order to define a type of payment that none of the three could cover on its own.

When these circulations are represented in both erudite and profane ways, they are associated with the language of dissent and this triple construction of the payment method is lost. Generally, the impression that remains is that the money was either a gift or compensation, thus pointing to how this money is fastened to personal debt or exploitation. Another way to interpret Mary and Salcedo's connection is within a perspective that attempts to capture the cycles of obligations, thus eluding this one-dimensional viewpoint. 
By introducing the concept of time, a uniform conception of the obligations is abandoned and the way in which agents act differently depending on the moment of the cycle can be considered. This way, entitlement and compensation are presented as possible meanings of the political payment when Salcedo's favor appears further off in time. The autonomy that Mary displayed during these periods was as real and important as the acquiescence she showed when the money that Salcedo "threw her way" allowed her to get through tough times.

According to this argument, political money is a combination of three types of payments. None of the three alone provides a comprehensive understanding of the meaning of money in the realm of politics. If the perspective of suspicious money can comprise only one side of these heterogeneous meanings (a side in which it is represented as selfish, compulsory, or merely practical), it is because suspicious money cannot capture the struggle for moral value that is at stake with political money. The positivity of this puzzle piece can thus be found in the efforts to have one's virtues acknowledged and to reveal the other's defects, the terrain where political ties are put to the test.

\section{References}

ARCHER, R. P. The transition form traditional to broker clientelism in Colombia: political stability and social unrest. Notre Dame: Kellogg Institute for International Studies, University of Notre Dame, 1990. (Working Paper \#140).

AUYERO, J. Poor people's politics: Peronist survival networks and the legacy of Evita. Durham: Duke, 2001.

BLOCH, M.; PARRY, J. Introduction. In: BLOCH, M.; PARRY, J. Money and morality of exchange. Cambridge: Cambridge University Press, 1989. p. 1-32.

BOLTANSKI, L.; THÉVENOT, L. De la justification: les économies de la grandeur. Paris: Gallimard, 1991.

BOURDIEU, P. The logic of the practice. Standford: Standford University Press, 1990. 
CERRUTI, M.; PARRADO, E. Migración de Paraguay a la Argentina: género, trabajo y familia en contextos de origen diferenciados. In: GRIMSON, A.; JELIN, E. Migraciones regionales hacia la Argentina: diferencia, desigualdad y derechos. Buenos Aires: Prometeo, 2006. p. 99-134.

DUMONT, L. Homo hierarchicus: le système des castes et ses implications. Paris: Gallimard, 1966.

EISENSTAD, S. N.; RONIGER, L. Patrons, clients and friends: impersonal relations and the structure of trust in society. Cambridge: Cambridge University Press, 1984.

ELIAS, N.; SCOTSON, J. Les logiques d'exclusion. Paris: Fayard, 1997.

GELLNER, E. Patrones y clientes en las sociedades mediterráneas. Barcelona: Jucar, 1986.

HAKIM, C. Erotic capital. European Sociological Review, Oxford, v. 26, n. 5, p. 499-518, 2010.

KESSLER, G. Controversias sobre la desigualdade. Buenos Aires: Fondo de Cultura Ecónomica, 2014.

KUSCHNIR, K. O cotidiano da politica. Rio de Janeiro: Jorge Zahar, 2000.

MAUGER, G. Les bandes, le milieu et la bohème populaire: études de sociologie de la déviance des jeunes des classes populaires (1975-2005). Paris: Belin, 2006.

MAUSS, M. The gift: the form and reason for exchange in archaic societies. New York: W. Norton \& Company, 2000.

MENÉNDEZ-CARRION, A. La conquista del voto en el Ecuador. Quito: Corporación Editora Nacional, 1986.

OFFERLÉ, M. Perímetros de lo político: contribuciones a una socio-historia. Buenos Aires: Antropofagia, 2011.

OSSONA, J. Punteros, malandras y pongas: ocupación de tierras y usos políticos de la tierra. Buenos Aires: Siglo XXI, 2014. 
SCHMIDT, S. et al. (Ed.). Friends, followers and factions: a reader in political clientelism. Berkeley: University of California Press, 1977.

SCOTT, J. Corruption, machine politics and political change. American Political Science Review, Washington DC, v. 63, n. 4, p. 1142-1158, 1969.

SIMMEL, G. Philosophie de l'argent. Paris: Presses Universitaires de France, 1996.

VILELLA, J. O dinheiro e suas diversas faces nas eleições municipais em Pernambuco. Mana, Rio de Janeiro, v. 11, n. 1, p. 267-296, 2004.

VOMMARO, G. Regards croisés sur les rapports des classes populaires au politique en Argentine: retour sur la question du "clientélisme”. 2010. PhD dissertation. École des Hautes Études en Sciences Sociales, Paris, 2010.

WHITE, W. F. Street corner society. Chicago: The University of Chicago Press, 1973.

WILKIS, A. Las sospechas del dinero: moral y economía en la vida popular. Buenos Aires: Paidos, 2013.

WILKIS, A. Sobre el capital moral. Papeles de Trabajo, Rosario, v. 8, n. 13, p. 164-186, 2014.

ZELIZER, V. The social meaning of money: pin money, paychecks, poor relief, and other currencies. Princeton: Princeton University Press, 1994.

ZELIZER, V. Payments and social ties. Sociological Forum, Randolph, v. 11, n. 3, p. 481-495, 1996.

ZELIZER, V. The purchase of intimacy. Princeton: Princeton University Press, 2005. 